\title{
The Federal Reserve in a Globalized World Economy
}

\author{
John B. Taylor ${ }^{1}$ \\ Stanford University \\ September 2014
}

Economic research as far back as the early 1980s showed that simple rules-based monetary policy would result in good economic performance in a globalized world economy. ${ }^{2}$ According to this research, if each central bank in the world followed a steady monetary policy rule that was optimal for its own country's price and output stability, it would also contribute to a framework of stability for the other countries. In fact, quantitative research showed that there would be little additional gain from the central banks' jointly optimizing their policies. This finding was, and still is, the implication of empirically estimated multi-country monetary models with highly integrated international capital markets, no-arbitrage conditions in the term-structure of interest rates, forward-looking expectations, and price and wage rigidities.

The historical experience of the Great Moderation period of the 1980s, 1990s, and until recently largely validated this result. As central banks moved toward more transparent rulesbased monetary policies—including through inflation-targeting—economic performance improved. The improvement was especially dramatic compared with the instability of the 1970s, when, following the demise of the Bretton Woods system, monetary policy was highly discretionary and unfocused. Mervyn King (2003) called it a NICE period for it was non-

\footnotetext{
${ }^{1}$ This paper was prepared for the Conference "The Federal Reserve's Role in the Global Economy: A Historical Perspective," hosted by the Federal Reserve Bank of Dallas. The paper focuses on monetary policy rather than on the regulatory parts of Federal Reserve policy. Some of the results are based on research prepared for the BIS (Taylor (2013c). I thank Michael Bordo, Claudio Borio, Richard Fisher, Arminio Fraga, Lawrence Goodman, Simon Hilpert, Ronald McKinnon, David Papell, Kenneth Rogoff, George Shultz, Volker Wieland and the staff of the Globalization and Monetary Policy Institute at the Federal Reserve Bank of Dallas for helpful comments and assistance.

${ }^{2}$ See, for example, the studies by Carlozzi and Taylor (1985), Taylor (1985, 1993), Clarida, Gali and Gertler (2002), Obstfeld and Rogoff (2002).
} 
inflationary and consistently expansionary. Toward the later part of this NICE Great

Moderation, central banks in many emerging market countries also moved toward more rule-like policies with long-run price stability goals. Their performance and their contribution to global stability also improved, especially compared with the earlier periods of frequent emerging market financial crises.

The situation had similarities to a game-theory equilibrium in which each country chose its own good monetary policy taking as given that other countries would do much the same under a basic understanding that the outcome would be nearly as good as if they coordinated their policy choices in a cooperative fashion. Attempts to coordinate policy choices across countries would likely have added little to the large improvement in macroeconomic stability during the Great Moderation, much as the monetary theory implied. For this reason, I doubled down on King's (2003) acronym and called the period a near internationally cooperative equilibrium (NICE). So we had Twice-NICE or NICE-squared. ${ }^{3}$

But during the past decade the situation has changed for the worse. We have seen the end of NICE in both senses of the word. The Great Recession and the Not-So-Great-Recovery in much of the developed world put an end for the time being to the Great Moderation. The large negative spillover effects and apparent lack of international monetary coordination have again become a major international policy issue. Policy makers in large emerging market countries, including Brazil, China and India, have complained about adverse spillover of monetary policy in the developed countries on their economies. Policy makers in developed countries including Japan and Europe have pointed to the adverse exchange rate effects of monetary policies in other developed countries and some have raised concerns about currency wars and competitive

\footnotetext{
${ }^{3}$ Taylor (2013c)
} 
devaluations. Many central banks in small open economies, such as Singapore, Hong Kong and Switzerland, have had to take unusual actions to prevent excesses in their countries.

As Volcker (2014) recently put it "new questions have been raised about the sensitivity of markets in small and emerging economies to the prospect of even small policy adjustments by the Federal Reserve. While the concerns and complaints of some officials in those countries may seem exaggerated, the volatility of short-term capital flows responsive to even a small shift in policy perception does raise important issues. And, there can be no doubt that major changes in circumstances and policies in industrialized countries do inevitably have world-wide repercussions.”

For these reasons there have been calls for a new approach to the international monetary system. The Institute for Globalization and Monetary Policy at the Dallas Fed was set up with the explicit purpose of researching the issue, and Richard Fisher (2014) has pin-pointed some of the most serious concerns about the current situation in monetary policy. The Bank for International Settlements (BIS) has been researching the causes of the increased spillovers and looking for reforms of the process of international monetary policy cooperation (Caruana (2012a, 2012b). The Center for Financial Stability held a $70^{\text {th }}$ anniversary conference in Bretton Woods earlier this month to consider such issues. Harking back to the 1944 Bretton Woods conference and "memories of a more orderly, rule-based world of financial stability, and close cooperation among nations,” Paul Volcker (2014) asks the fundamental question:

What is the approach (or presumably combination of approaches) that can better reconcile reasonably free and open markets with independent national policies, maintaining in the process the stability in markets and economies that is in the common interest? 
Deciding on what is the correct approach requires a good diagnosis of the problem. In my view the recent change in the international monetary situation is mainly due to monetary actions deviating from steady-as-you-go rule-like policies. The same monetary research from the 1980s that predicted that NICE-squared would be the result of rule-like policy would also predict the demise of NICE-squared in the event of a prolonged deviation from rule-like policy. And in fact, recent empirical research shows that such a deviation occurred in the United States and some other countries, starting about a decade ago—well before the financial crisis—when interest rates were held very low. ${ }^{4}$

Indeed, there has been a "Global Great Deviation" to use the terminology of Hofmann and Bogdanova (2012), who show that the deviation is continuing to the present when unconventional central bank interventions and large-scale balance sheet operations are included. The response of central banks to the deviations of policy of other central banks causes them to deviate together from the optimal policy that would otherwise be appropriate based on their own domestic considerations. The Bank of Japan's recent quantitative easing actions were in part a response to the adverse spillover on the exchange rate of the easier policy in other G7 countries. ${ }^{5}$

This paper starts from these theoretical and historical observations and tries to answer the question posed by Paul Volcker. It starts by explaining the basic theoretical framework, its policy implications, and its historical relevance. It then reviews the empirical evidence on the size of the international spillovers caused by deviations from rules-based monetary policy, and explores the many ways in which these spillovers affect and interfere with policy decisions globally. Finally, it considers ways in which individual monetary authorities and the world

\footnotetext{
${ }^{4}$ See Ahrend (2010), Kahn (2010) and Taylor (2007).

${ }^{5}$ The Bank of Japan also announced an inflation target to 2 percent, which has an element of international cooperation because that is close to the numerical target of the Fed and the ECB.
} 
monetary system as a whole could adhere better to rules-based policies in the future and whether this would be enough to achieve the goal of stability in the globalized world economy.

\section{Policy Tradeoffs in a Globalized World Economy}

The idea that monetary policy rules deliver good economic performance in a globalized world economy comes out of a multi-country monetary modelling framework that I have been using in research and graduate teaching for many years (Carlozzi and Taylor (1985), Taylor (1993, 2013a)). ${ }^{6}$ It assumes perfect capital mobility (as in the original Dornbush-MundellFleming model), which is of course quite appropriate for a "globalized world economy.” It also assumes staggered wage and price setting as in the Taylor (1980) model, so that inflation today depends in part on inflation in the future. Domestic prices in each country are affected by both domestic wages and the price of foreign imports, so the law of one price does not hold in the short run. Output in each country is influenced by the real interest rate, the real exchange rate, and expectations of future output due to forward-looking consumers who take account of their future income prospects when deciding how much to consume. Shocks can hit anywhere in the economy and may be due to shifts in preferences or technology. Shocks to the wage and price setting process are central to the modeling framework and preclude from the start any miraculous divine coincidence, as defined by Blanchard and Gali (2007). Indeed, the essence of the monetary policy problem is characterized by a policy tradeoff between price stability and output

\footnotetext{
${ }^{6}$ The field of multi-economy monetary economics is, of course, vast and has evolved significantly over the years. Clarida, Gali and Gertler (2002) built a two-country model with explicit micro-foundations in order to evaluate monetary policy rules in a global context. Carabenciov, Freedman, Garcia-Saltos, Laxton, Kamenik and Manchev (2013) have built on such work in empirical research that can be traced back to the empirical models compared by Bryant, Hooper, and Mann (1993). Clarida (2014) provides a modern and practical perspective and Obstfeld (2014) adds a useful discussion. Since the financial crisis many other policy issues have required consideration, including forward guidance, quantitative easing, the incorporation of credit spreads into policy rules, and the comparison of rules actually used by the Fed as found in recently released transcripts.
} 
stability. The task of monetary policy in each country is to find a policy in which the policy instrument is adjusted so as to reach an efficient point on that tradeoff.

In such a model, the problem for the central bank is to decide how to respond to shocks and fluctuations in the economy while not creating its own shocks and disturbances either domestically or internationally. By choosing the size of its response coefficients, it can affect the relative amount of price stability and output stability. For example, when the interest rate reaction coefficient on inflation increases, then price stability increases and output stability falls. Conversely, if the central bank chooses to react less to inflation changes, then there will be less price stability but more output stability. And by minimizing deviations from its optimal policy responses—-that is, by not adding shocks to its policy rule—it will minimize monetary policyinduced fluctuations.

The sense in which the gains from international policy coordination are small in such a modelling framework is that the central bank's choice of a policy rule - in this case the decisions to be more or less responsive- - has relatively little impact on output and price stability in the other countries. Figure 1 illustrates the idea in the case of two countries. It shows the tradeoff between output and price stability in Country 1 , on the left, and Country 2, on the right. Measures of the size of output and price fluctuations are on the vertical and horizontal axes, respectively. The tradeoff curve is like a frontier. Points on the curve represent optimal policy. Monetary policy cannot take the economy to infeasible positions to the left or below the curve. But suboptimal monetary policy—due to policy errors, reacting to the wrong variables, etc.—can take the economy to inefficient higher variability points above and to the right of the curve. Along the curve, lower price variability can only be achieved with greater output variability corresponding to different values of the reaction coefficient. The existence of such a tradeoff 
curve is quite general, and the curve has been used in many different monetary policy studies going back to the 1970s and continuing today ${ }^{7}$

The shape and the position of the tradeoff curve depend on the parameters of the model and the size of the shocks. An increase in the variance of the shock to wage setting in one country, for example, will move that country’s curve up and to the right. A reduction in the size of the response of wages to the state of the economy - effectively more price-wage stickinesswill also result in a shift in the tradeoff curve in the northeast direction.

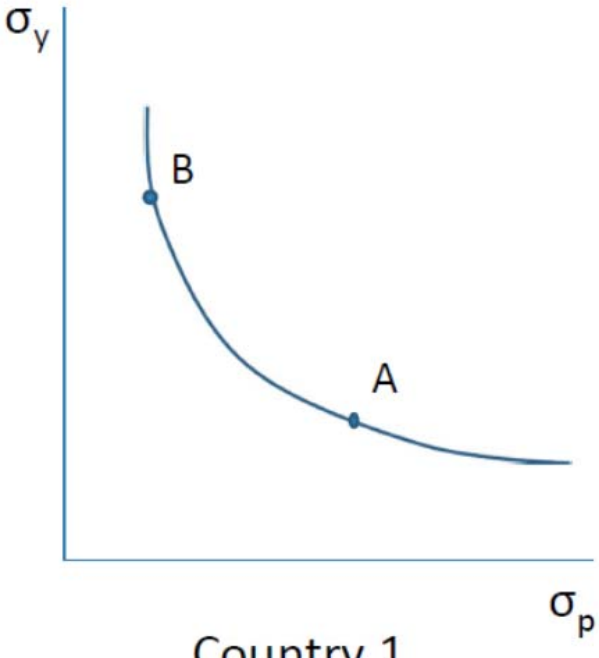

Country 1

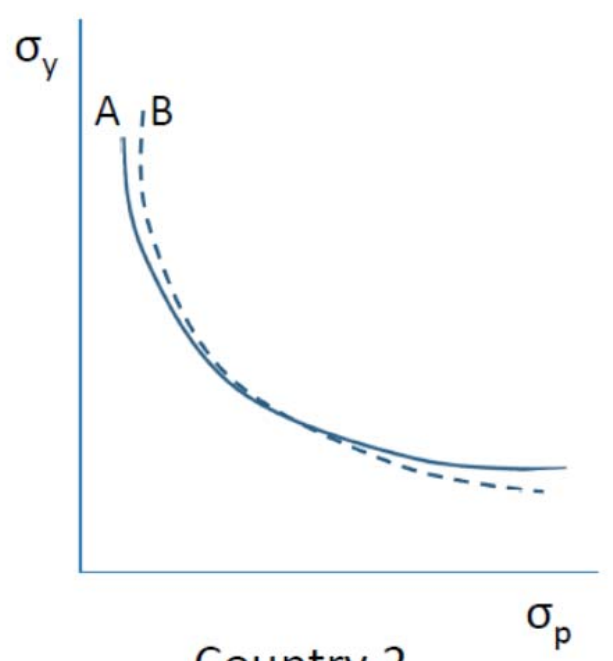

Country 2

Figure 1: Illustration of the NICE Idea. If Country 1 chooses Optimal Policy B rather than Optimal Policy A, then the policy frontier in Country 2 shifts from Curve A to Curve B, or by a very small amount. This result also holds in reverse if Country 2 changes its policy.

Points A and B, which are on the tradeoff curve for Country 1, represent two alternative choices for optimal policy, reflecting different weights on the macroeconomic objective function for Country 1. The policy at point A results in a relatively small variance of output and a relatively large variance of prices compared with point B. The two different tradeoff curves for

\footnotetext{
${ }^{7}$ See Taylor (1979), Bernanke (2004) and King(2012)
} 
Country 2 show the effect on Country 2 of a change in policy in Country 1 from A to B. The important point is that the tradeoff curve for Country 2 is virtually the same regardless of which of the optimal policies are chosen by Country 1 . Curve B is drawn with a slight twist relative to Curve A, but that is not a general result. Note that the same type of diagram would show that a change in policy in Country 2 would have little change in Country 1.

This is the sense in which there is little to be gained by Country 2 coordinating its own policy rule with Country 1 . In game theory terminology, macroeconomic performance under a Nash non-cooperative monetary policy is nearly as good as under the optimal cooperative monetary policy, and far superior to a policy which is suboptimal on purely domestic grounds. If the modelling approach implied that the Country 2 curve shifted by a lot with a change from one optimal policy to another optimal policy in Country 1, and vice versa, then the cooperative monetary policy might be worth pursuing even if the policies were optimal from a domestic point of view. ${ }^{8}$

The tradeoff curves can also be used to illustrate how deviations from an optimal policy rule can lead to a breakdown in the international policy equilibrium. This is shown in Figure 2. Suppose Country 1 deviates from its optimal monetary policy rule and moves in the direction of an inefficient policy as shown by point C in Figure 2. The impact in Country 2 will most likely be large for two separate, but not mutually exclusive, reasons.

First, the tradeoff curve in Country 2 would likely shift out. The instability caused by the change in policy in Country 1 could spill over to Country 2, for example, in the form of more volatile export demand, as was demonstrated vividly in the financial panic in late 2008, or simply in more volatile exchange rates or commodity prices. Bordo and Lane (2013) have

\footnotetext{
${ }^{8}$ Recall that I am only considering monetary policy here. Eichengreen (2013) argues that countries can use fiscal policy if they are constrained in the use of monetary policy due to international considerations.
} 
shown that policy deviations can have a variety of adverse effects on economic performance which can be transmitted globally. These shocks would be very hard for even the best monetary policy to fully counteract. Figure 2 shows this shift in the tradeoff curve in Country 2; the original curve - either A or B — moves out to the curve with the long dashed lines. Hence Country 2 is forced to the point $\mathrm{C}$, or perhaps to another point on the new less-favorable tradeoff. Second, the change to a less efficient monetary policy in Country 1 might bring about a change to a less efficient monetary policy in Country 2. For example, if the policy change in Country 1 is to bring about an excessively easy policy with very low interest rates, then the policy makers in Country 2 may be concerned about exchange rate appreciation and thus keep their interest rate too low too-deviating from their policy rule—which could cause an increase in price volatility and output instability. The central bank might do this even if there was an offsetting effect from higher export demand from higher output in Country 1 . They might perceive that offsetting effect to be too low or too delayed or they may be concerned about the hit to certain export sectors. Of course it is possible that both international effects of the change in policy in Country 1 occur at the same time, in which case the outcome could be point $\mathrm{D}$ in the right hand panel of Figure 2. 

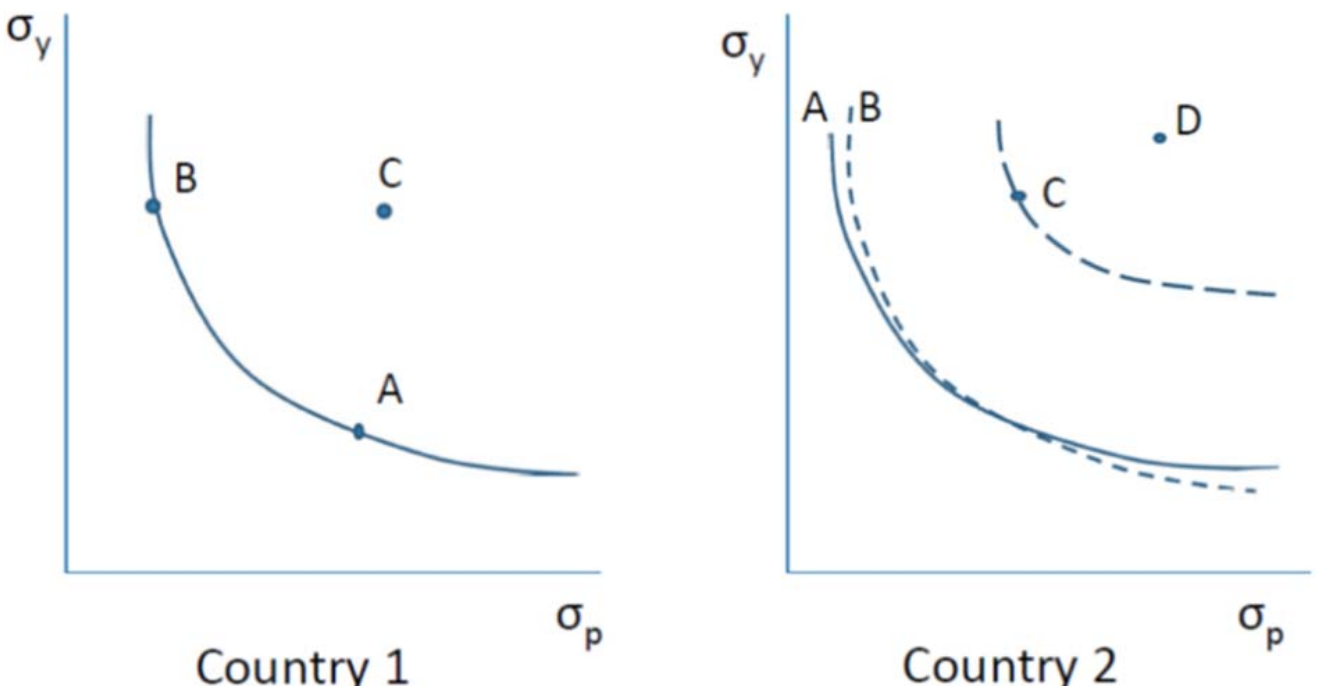

Figure 2. Illustration of a Not-So-NICE Idea. If Country 1 deviates from its optimal policy rule, moving to point $\mathrm{C}$, then the impact on Country 2 can be quite large: It either causes Country 2 to choose a poor policy rule $\mathrm{C}$ with no change in the tradeoff, or it causes the tradeoff curve to shift out, or both as in point $\mathrm{D}$.

\section{Historical Interpretation}

The historical interpretation of the past half century put forth in this paper is that the world economy moved from the situation like Figure 2 to Figure 1 and then back to Figure 2 as policy became more rules-based and then less rules-based. Evidence for the first shift in policy was provided early on by Clarida, Gali, and Gertler (1998) and later confirmed by many others including recently by Nikolsko-Rzhevskyy, Papell, and Prodan (2014) who use modern time series techniques and also provide evidence for the second shift. Clarida (2014) cites considerable research that shows that the connection between the policy and the economic performance "was no coincidence,” adding that many research papers "show that, in dynamic stochastic general equilibrium models with nominal rigidities, flexible exchange rates and inflation targeting produce desirable macroeconomic outcomes in open economies.” 
While there is general agreement about the first shift in policy there are different views about the second. The main alternative view is based on the idea that the monetary policies undertaken by the central banks have been appropriate in recent years, even if they are not consistent with the rule-like behavior followed during the NICE-Squared period. Yellen (2012) argues, for example, that "the simple rules that perform well under ordinary circumstances just won’t perform well with persistently strong headwinds restraining recovery...”

According to this alternative view, the shift in economic performance in Figure 2 was not due to monetary policy deviating from a rules-based approach. Any shift in the tradeoff curve was due to other factors. Rather than being due to monetary policy in Country 1 moving off the tradeoff curve to the inefficient point C, the curve in Country 2 shifted for other reasons.

Mervyn King (2012), for example, has made this argument using the same tradeoff curve diagram. He argues that the tradeoff curve shifted out because financial stability during the Great Moderation eventually bred instability, largely through the complacency of investors who, thinking that stability conditions would continue, took on too much risk and thereby increased instability. The idea is due to Hyman Minsky, so King argues that the Taylor curve shifted to a new Minsky-Taylor curve. As he puts it, "A failure to take financial instability into account creates an unduly optimistic view of where the Taylor frontier lies, especially when it is based on data drawn from a period of stability. Relative to a Taylor frontier that reflects only aggregate demand and cost shocks, the addition of financial instability shocks generates what I call the Minsky-Taylor frontier.”

Bernanke (2013) seems to go further than King (2012) in this line of argument. In terms of the Figure 2 he argues that the effect of what I call a policy deviation in Country 1 on policy in Country 2 is actually entirely appropriate. He compares recent monetary policy shifts to what 
happened during the Great Depression when countries moved off the gold standard and started what were called competitive devaluations, but in essence were a move toward more monetary ease.

\section{Global Impacts of Deviations from Monetary Policy Rules}

Now consider the quantitative size and nature of the spillover effects of deviations from policy rules as evidenced by empirical multi-economy modeling frameworks. I consider two multi-country monetary models: the TMCM, which includes the United States and other developed countries, described in Taylor (1993) ${ }^{9}$ and GPM6, the IMF global model, which includes the United States, other developed countries, and emerging market countries in Latin American and Asia. GPM6 is described in Carabenciov, Freedman, Garcia-Saltos, Laxton, Kamenik, Manchev (2013). ${ }^{10}$ Calculations by Taylor and Wieland (2012) show that the TMCM has effects in the United States of monetary shocks that are very similar to the new Keynesian models of Christiano, Eichenbaum and Evans (2005) and Smets and Wouters (2007).

Figure 3 and Figure 4 show the impact of deviations from monetary policy rules in the two models for several key variables and a selection of countries or regions. In Figure 3 the impacts on the United States and Japan are compared while in Figure 4 the impact on the United States is compared with Japan as well as with the Latin American countries (LA 6, which include Brazil, Chile, Colombia, Mexico and Peru) and emerging Asia countries (EA6, which include China, India, South Korea, Indonesia, Taiwan, Thailand, Malaysia, Hong Kong, Philippines and Singapore).

\footnotetext{
${ }^{9}$ Simulations of the TMCM model reported here were run via the model database constructed and maintained by Volker Wieland; see Wieland et al (2012).

${ }^{10}$ Simulations in the GPM6 model reported here were run at the IMF by Roberto Garcia-Saltos
} 

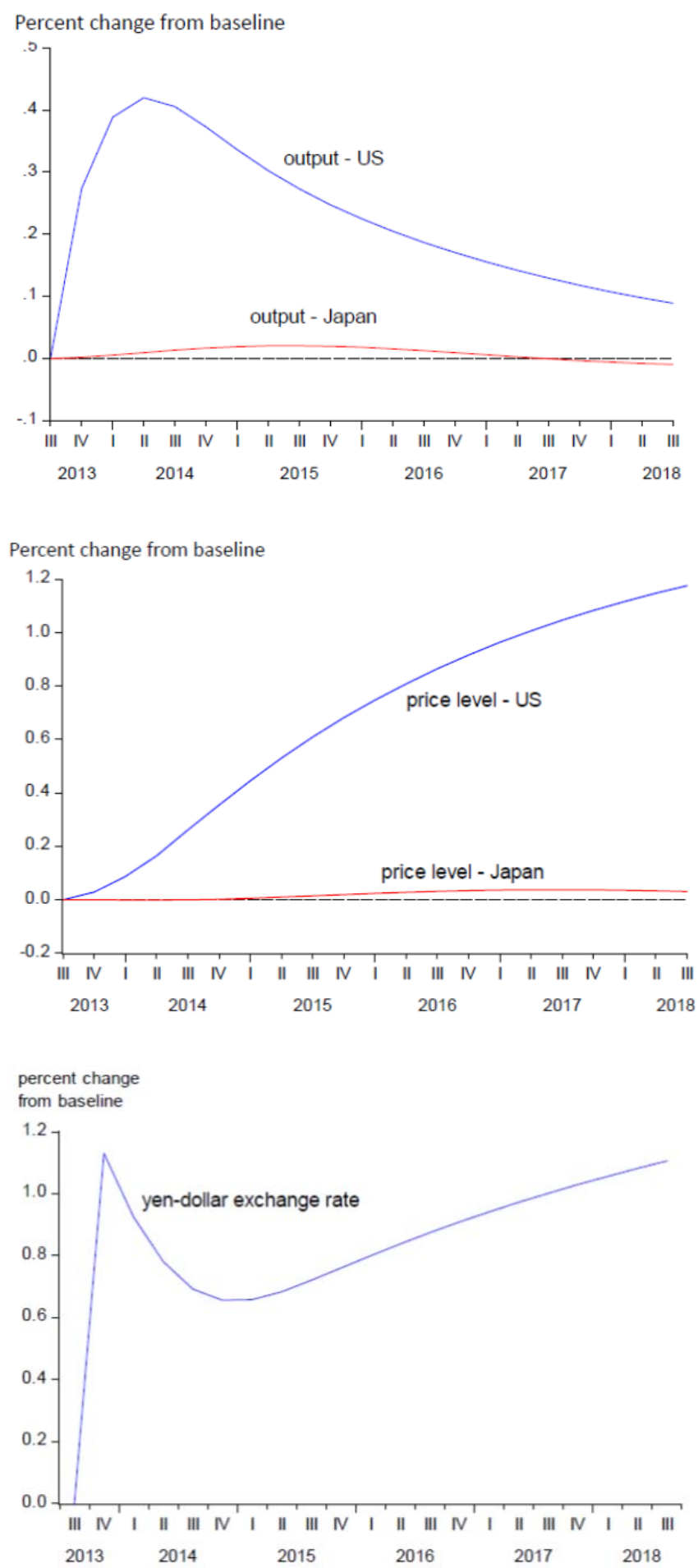

Figure 3: Exchange Rate and Output-Price Effect of a US Policy Rule Deviation. The figure shows the impact, according to the TMCM, on the exchange rate and on output and prices in the US and Japan of a one percent negative deviation (reduction) from the policy rule phased out at rate 0.9 . 

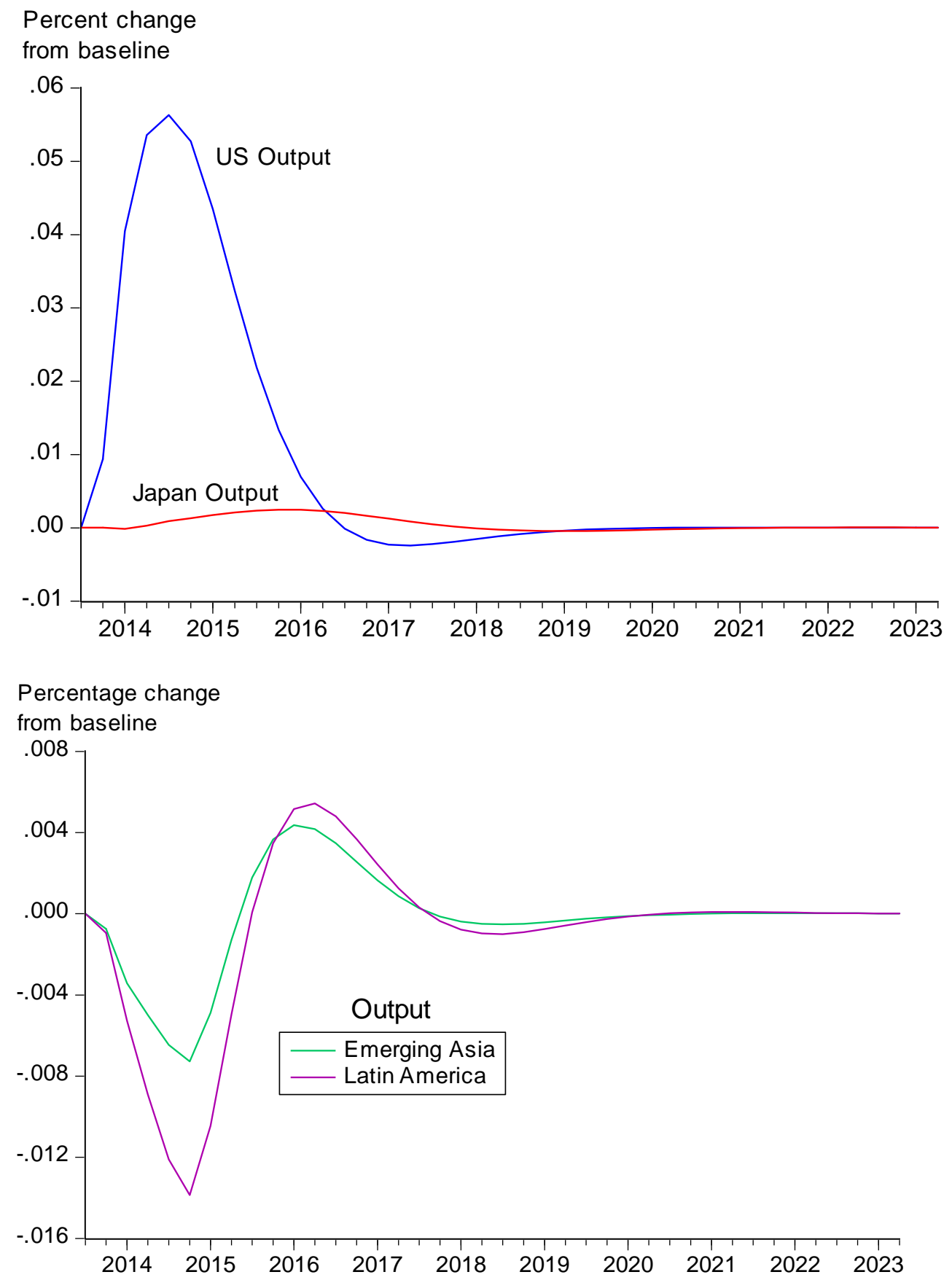

Figure 4: Exchange Rate and Output-Price Effect of a US Policy Rule Deviation Impact on the exchange rate and output and prices, according to GPM6, of a temporary negative shock to US interest rate rule of 0.2 percentage points. 
In each case the monetary shock is a deviation from the monetary policy rule in the United States. Note that in interpreting the graphs that the deviations are of different sizes in the two models. In Figure 3 the deviation initially causes the interest rate to fall by about .8 percentage points and then slowly move up with the interest rate back to the starting point in about 5 quarters. In Figure 4, the deviation initially causes the interest rate to fall by about .2 percentage points and then the dynamics of the policy rule lead to a gradual rise in the interest rate back to its starting point in about 5 quarters. In both simulations the interest rate overshoots before returning to normal due to the response of the policy rule to the economy after the shock.

First observe the large impact of the policy deviation on the exchange rate in both models. The simulations show that the dollar depreciates by 1.4 percent for each percentage point decrease in the U.S interest rate in the TMCM and by 1.0 percent in GPM6 (not shown in the figures).

Next consider the impact of the change in short term interest rate and the resulting change in the exchange rate on U.S. output in both Figure 3 and Figure 4: the percentage increase in output for a percentage point reduction in the interest rate is about 0.5 in Figure 3 and 0.25 in Figure 4. Simulating other estimated multi-country models, shows impacts in this same general range. For example, similar simulations of the Fed's SIGMA model vintage 2008 and the ECB's New Area Wide Model (NAWM) also vintage 2008 - two other models in the Volker Wieland et al (2009) model data base-show, respectively, impact effects on output of .19 and .28 percent for each percentage point deviation in the policy rule for the short-term interest rate.

Finally, consider the impact on output in other countries. According to the GPM6 model this exchange rate change translates into a negative effect on output in the Latin American and the Asian emerging market economies. For each percentage point monetary policy-induced 
increase in output in the United States, output falls by .25 percentage points in the Latin American countries and by .13 percentage points in the emerging Asian countries. As described by the authors of the IMF's GPM6 model this occurs in these countries because "the exchange rate channel is stronger than the direct output gap effect.” The impact on other developed economies' output is not negative, but it is quite small. For example, Japan’s output increases by only about $1 / 20$ th of the U.S. output increase in both models.

These estimates contradict the view sometimes put forth by central bankers in the US and other developed countries when discussing policy spillovers. Bernanke (2013), for example, argued that "The benefits of monetary accommodation in the advanced economies are not created in any significant way by changes in exchange rates; they come instead from the support for domestic aggregate demand in each country or region. Moreover, because stronger growth in each economy confers beneficial spillovers to trading partners, these policies are not 'beggarthy-neighbor' but rather are positive-sum, 'enrich-thy-neighbor' actions.” The policy simulations in these empirical multi-country models do not, however, support an enrich-thy-neighbor view.

When one moves beyond these multi-economy models and considers unconventional monetary policy, there are more reasons to doubt the enrich-thy-neighbor characterization. If the monetary policy action is mainly in the form of quantitative easing, the standard term structure models are not applicable and there is a great deal of debate about whether there is a positive effect on aggregate demand. Stroebel and Taylor (2012) found very little effect of large-scale purchases on mortgage rates when controlling for other risks, and the announcement effects detected by Gagnon et al (2011) likely phase out over time. 


\section{Monetary Policy Contagion}

These simulations illustrate why in practice a large policy deviation at one central bank puts pressures on central banks in other countries to deviate from their otherwise optimal policy. As the empirical models show, a reduction in policy interest rates abroad causes the exchange rate to appreciate. Even though there may be countervailing effects of the low foreign interest rates because economic output abroad is stimulated (the trade effect in the model simulations), this effect may occur with a lag in practice and is less visible than the exchange rate appreciation. Moreover, for the emerging market countries in Latin America and Asia, the exchange rate effect dominates according to the empirical model simulations. More generally, there is not enough empirical evidence to support the view that a pickup in output abroad will offset the appreciation. Moreover, in recent years the pickup abroad has not materialized. Hence, many central banks will tend to resist large appreciations of their currency, and one way to do so is to reduce their own policy rate relative to what it would be otherwise. This will reduce the difference between the foreign interest rate and the domestic interest rate and will thus mitigate the appreciation of their exchange rate.

Another concern of some central banks is that very low interest rates at the major central banks can increase risky capital flows in their countries, as shown by Bruno and Shin (2012), and one way to combat this is to lower the policy interest rate. Firms abroad are able to borrow in dollars to finance investment projects even though the returns on these projects are denominated in local currency. The loans made to the firms by banks to fund these projects are subject to default in the event that the project earns less than the loan, including interest payments. In such a circumstance, a central bank can mitigate the increase in foreign lending by keeping its own interest rate lower than it otherwise would for domestic stability purposes. This reduces the 
incentive to borrow abroad and the associated risk. In the end, an extra low interest rate policy in one country leads to a similar deviation in other countries. ${ }^{11}$

There is considerable empirical evidence of the impact of foreign interest rates on central bank decisions. The best evidence comes from central bankers themselves, many who readily admit to these reactions in conversations. Some issue public reports. Consider the Norges Bank which provides a great deal of detail about its decisions and the rationale for them. ${ }^{12}$ In 2010 , for example, the Norges Bank explicitly reported that it lowered its policy interest rate because interest rates were lower abroad. The Norges Bank provides reports on the details of its own policy rules, and there was a large deviation in 2010 . The actual policy rate, at about $2 \%$, was much lower than the rate implied by its domestic monetary policy rule, which called for a policy rate of about $4 \%$. This deviation was almost entirely due to the very low interest rate abroad, according to the Norges Bank. It reported that a policy rule with external interest rates included came much closer to describing the actual decisions than the policy rules without external interest rates.

The recent case of the Bank of Japan's move toward quantitative easing and large-scale asset purchases provides another example. Following the financial crisis and into recovery, the yen significantly appreciated against the dollar as the Fed repeatedly extended its zero interest rate policy and its large scale asset purchases. Concerned about the adverse economic effects of the currency appreciation, the new government of Japan urged the Bank of Japan to ease up on policy and implement its own massive quantitative easing, and, with a new Governor at the Bank

\footnotetext{
${ }^{11}$ In discussions with many central bankers I hear more concerns about exchange rates than about capital inflows, but the actual reasons for deviating from conventional policy rules are inherently complex. A preference for discretion rather than rules-based policies has become more common among central bankers, especially in the aftermath of a financial crisis when the "rule-book" is often thrown away. Moreover, governments have become more aggressive in asking central banks to take unconventional actions if other central banks are doing so.

${ }^{12}$ See Røisland (2010), the OECD Survey (2010), and Taylor (2013b).
} 
of Japan, this is exactly what happened. As a result of this change in policy the yen fully reversed its course and has returned to the exchange rate just before the panic of 2008. In this way the policy of one central bank appeared to affect the policy of another central bank.

The recent moves of the ECB toward quantitative easing of some kind may have similar motivations. An appreciating euro was in the view of the ECB a cause of both the low inflation and the weak economy. With the prolonged zero interest rates in the US, an understandable response was to shift to even lower rates in the Eurozone and the initiation of quantitative easing. Indeed, the shift and initiation was followed by a dollar strengthening and a weaker euro.

There is considerable econometric evidence of the spread of central bank policies based on the statistical correlations between policy interest rates in different countries. Gray (2013) estimated policy rate reaction functions in which the U.S. federal funds rate or other measures of foreign interest rates entered on the right hand side as deviations from their respective policy rules. He used panel data from 12 central banks (Australia, Canada, South Korea, the United Kingdom, Norway, New Zealand, Denmark, Israel, Brazil, the Eurozone, China, and Indonesia), and found that the average reaction coefficient on the foreign rate was large and significant.

There is also evidence that shifts in monetary policy in the form of quantitative easing have an impact on monetary policy decisions abroad. Chen, Filardo, He and Zhu (2012) examine the impact of various types of quantitative easing in the United States, the United Kingdom, the ECB and Japan on monetary conditions in emerging market countries and in other advanced economies. They find that "the announcement of QE measures in one economy contributed to easier global liquidity conditions.” 


\section{A Policy Deviations Multiplier}

Deviations from rules-based monetary policy aimed at avoiding the competitive devaluation effects of exchange rate changes can have large multiplier effects. Consider the case of an interest rate rule and two countries. In this case the multiplier can be illustrated with a simple diagram. $^{13}$

Suppose $i$ is the policy interest rate at one central bank and $i_{f}$ is the policy interest rate at the other central bank. Assume that each central bank tends to deviate from its own policy rule in order to prevent competitive devaluations effects originating from abroad from actually having a competitive effect. Thus the amount of the deviation would depend on interest rate settings at the central bank in the other country. (Taylor 2009, 2013c)

Figure 5 shows an example of two reaction functions in which the first central bank has a response coefficient of .5 on the second central bank's policy interest rate and the second central bank has a response coefficient of 1 on the first central bank's interest rate. Suppose the first central bank cuts its interest rate $i$ by 1 percentage point below its normal policy rule setting. Then, the second central bank will also reduce its policy rate $i_{f}$ by 1 percentage point, which causes the first central bank to cut its interest rate by another .5 percentage point leading to another cut at the second central bank, and so on. In this example the end result is a 2 percentage point rate cut once the iterative process settles down. The initial deviation from the policy rule of 1 percentage point by the first central bank is multiplied by 2 in this example, ending up reducing the policy rates in both countries by 2 percentage points.

The end effect of these iterations is to thwart the competitive devaluation. But what may have appeared as a currency war ends up as an interest rate war, or even an unconventional monetary policy war.

\footnotetext{
${ }^{13}$ A similar case can be made if the policy instrument is quantitative easing.
} 


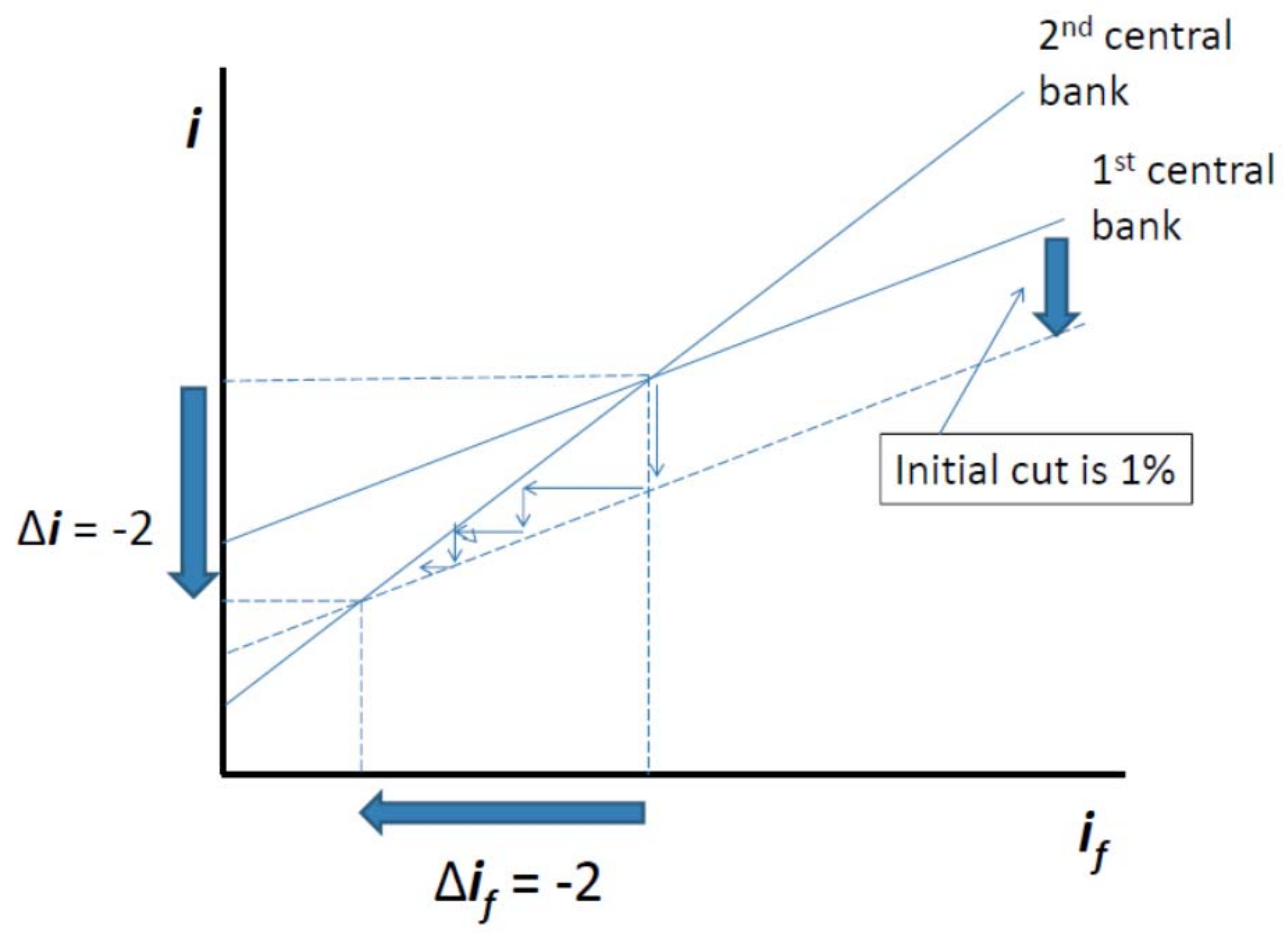

Figure 5: The Policy Deviations Multiplier: Each central bank matches, at least in part, the interest rate change at the other central bank. This creates a multiplier effect in which final interest rate change is much larger than the initial change.

\section{Capital Controls}

Concerned about the ramification of deviating from their normal monetary policy, many central banks have looked for other ways to deal with the impacts of policy deviations abroad, which during recent years have been characterized mainly by unusually low interest rates at foreign central banks. The imposition of capital controls is one approach. Capital controls limit the flow of capital and are usually aimed at containing the demand for local currency and its appreciation, but also to mitigate risky borrowing and volatile capital flows.

However, capital controls create market distortions and may lead to instability as borrowers and lenders try to circumvent them and policy makers seek even more controls to prevent the circumventions. Indeed, capital controls are one reason why the output and price 
stability frontier will shift adversely. Capital controls also conflict with the goal of a more integrated global economy and higher long-term economic growth.

Nevertheless, the unusual spillovers of recent years have led even the International Monetary Fund to suggest that capital controls might be used as a defense despite these harmful side effects. And the Federal Reserve has endorsed the approach, with, for example, Bernanke (2013) saying that “...the International Monetary Fund has suggested that, in carefully circumscribed circumstances, capital controls may be a useful tool.”

\section{Currency Intervention}

Currency intervention is another way to prevent unwanted appreciation of a currency either as an alternative or as a supplement to lower interest rates. In fact, currency intervention has been used widely in recent years by many emerging market countries. However, currency interventions can have adverse side effects even if they prevent appreciation for a while. Currency intervention leads to an accumulation of international reserves which must be invested somewhere. In the case where the low policy interest rates is set in the United States, the gross outflow of loans due to the low policy rates is accompanied by a gross inflow of funds from central banks into dollar denominated assets, such as U.S. Treasury or mortgage-backed securities which affects prices and yields on these securities.

Borio and Disyatat (2011) and Beckworth and Crowe (2012) analyzed the possible adverse effects of these flows during the period of the low federal funds rate in the United States in 2003-2005. They show that the inflow of funds from abroad into U.S. mortgage backed securities helped keep mortgage rates low, worsening the housing boom leading up to the 
financial crisis. In this case the policy deviation not only had an effect on the policy tradeoffs abroad, it fed back on the policy tradeoff in the United States.

\section{Macro-Prudential Policies as an Imperfect Substitute for Good Monetary Policy}

Another policy reaction has been the increased use of substitutes for monetary policy when the conventional policy is impacted by policies from abroad. This is most obvious in small open economies closely tied to the major currencies. Both Singapore and Hong Kong have had near zero short term interest rates in recent years because the Fed has had zero rates. Their pegged exchange rate regimes and open capital markets have left no alternative. So in order to contain inflationary pressures they have had no choice but to resort to discretionary interventions in housing or durable good markets, lowering required loan to value ratios in housing or requiring larger down payments for automobile purchases. Similarly Switzerland has introduced explicit restrictions on housing in order to contain a housing boom in the face of near zero interest rates.

These policies are also becoming more popular in inflation targeting countries with flexible exchange rates. Discouraged from leaving interest rates at appropriate levels because of exchange rate concerns, they turn to such market specific measures. These so-called macroprudential actions are inherently discretionary, expand the mission of central banks and bring them closer to politically sensitive areas. They also run the risk of becoming permanent even after unconventional policies abroad are removed. A regulatory regime aimed at containing risk taking is entirely appropriate, but that entails getting the levels right, not manipulating them as a substitute for overall monetary policy. 


\section{What to Do}

For all these reasons, deviations from rules-based monetary policy are likely to be a key driver of instabilities in the international monetary system. There are many reasons for the spread of these deviations and other potentially distortionary policies—which I have documented here- - but the understandable desire to prevent excessive exchange rate fluctuations and large risky capital flows are the main ones.

The obvious implication is that going forward the goal should be to return to more rulesbased monetary policies similar to what existed during the 1980s, 1990s and until recently, and now certainly including the emerging market countries. Such a system would likely operate near an international cooperative equilibrium as described above.

Can anything be done to help this along? I have argued that, for the United States, legislation may be needed, and recently some legislative action is underway. The first main section, "Requirements for Policy Rules for the Fed" of a bill recently passed out of Committee in the United States House of Representatives would require that the Federal Reserve report publically a rule or strategy for how the policy instruments, such as the federal-funds rate, would change in a systematic way in response to changes in inflation, real GDP or other inputs. The rule would have to be consistent with the setting of the actual federal-funds rate at the time of its report.

The Fed would choose the rule and how to describe it. But if it decided to deviate from its rule or modify its rule-say because the Fed's estimates of the long-run equilibrium real interest rate change - then the Chair of the Fed would have to testify in Congress and explain why.

Such legislation preserves the independence of the Fed to choose its monetary policy strategy. It does not require that the central bank hold any instrument of policy fixed, but rather 
that it make adjustments in a systematic and predictable way. The central bank can serve as lender of last resort or take appropriate actions to provide liquidity in a crisis, and even change its rule or deviate from it if policy makers decide that is necessary, but if it did it would submit an explanation.

Some say that such legislation would reduce central-bank independence, but since the central bank chooses its own rule, its independence is effectively maintained. The purpose of the act is to prevent the damaging departures from rules-based policy, which central-bank independence has not prevented.

Such legislation would limit discretion and excessive intervention in an accountable way. It meets Milton Friedman's goal of "legislating rules for the conduct of monetary policy that will have the effect of enabling the public to exercise control over monetary policy through its political authorities, while at the same time ... prevent[ing] monetary policy from being subject to the day-by-day whim of political authorities." Friedman (1962, p. 51)

But what about other central banks in the globalized world economy? A clear commitment by the Federal Reserve to move in this direction — whether aided by legislation or not—would help by influencing other central banks and the international financial institutions. An international understanding and agreement would help further. The major central banks now have a common inflation target and converging views about how the policy instruments should respond. This makes agreement about a policy strategy for the instruments more feasible. Such an agreement could instruct the IMF or the BIS, or even ask non-profit groups, to monitor the extent to which central bank policies are steady and rule-like. They could use the same procedures as in the current US legislation, or something which recognizes the widely different institutional frameworks within each country. 
Would such an approach be enough? Empirical evidence points in that direction. The large destabilizing capital flows motivated by search for yields would diminish. Rey (2013) has shown that a good portion of these flows has been induced by erratic swings in monetary policy which would be reduced greatly. And the large capital movements associated with "fear of free falling” exchange rates, which Vegh and Vuletin (2012) have documented, would likely be calmed as reliable central bank actions come to be expected. Indeed, research by Vegh and Vuletin indicates that the adoption of rules-based inflation targeting has already had that effect in a number of emerging market countries.

Historical experience, informed by economic theory and research, indicates that with this approach each country could choose its own independent monetary policy strategy while contributing to the common interest of global financial and economic stability and without interfering with the principles of free and open markets. 


\section{References}

Ahrend, Rudiger (2010), “Monetary Ease: A Factor Behind Financial Crises? Some Evidence from OECD Countries,” Economics: The Open Access, Open Assessment E-Journal, 4

Beckworth, David and Christopher Crowe (2012) “The Great Liquidity Boom and the Monetary Superpower Hypotheses,” in Boom and Bust in Banking: Causes and Cures of the Great Recession, David Beckworth, (Ed.), Oakland California: The Independent Institute. 17-54

Bernanke, Ben (2004), “The Great Moderation,” Eastern Economic Association, Washington, DC, February 20

Bernanke, Ben (2013), “Monetary Policy and the Global Economy,” London School of Economics, March 25

Blanchard, Olivier and Jordi Galí (2007), “Real Wage Rigidities and the New Keynesian Model,” Journal of Money, Credit, and Banking 39: 35-65

Bordo, Michael and John Landon Lane (2013) “Does Expansionary Monetary Policy Cause Asset Price Booms: Some Historical and Empirical Evidence,” NBER Working Papers 19585.

Borio, Claudio and Piti Disyatat (2011), “Global Imbalances and the Financial Crisis: Link or No Link?” Bank for International Settlements, Working Paper, 346, May.

Bruno, Valentina and Hyun Song Shin (2012), “Capital Flows and the Risk-Taking Channel of Monetary Policy,” paper presented at the 11th BIS Annual Conference, June.

Bryant, Ralph, Catherine L. Mann, and Peter Hooper (Eds.), (1993). Evaluating Policy Regimes: New Research in Empirical Macroeconomics, The Brookings Institution, 1993 
Carabenciov, Ioan, Charles Freedman, Roberto Garcia-Saltos, Douglas Laxton, Ondra Kamenik, Petar Manchev (2013) “GPM6: The Global Projection Model with 6 Regions,” IMF Working Paper, WP/13/87

Carlozzi, Nicholas and John B. Taylor (1985), “International Capital Mobility and the Coordination of Monetary Rules” in J. Bhandhari (ed.) Exchange Rate Management Under Uncertainty, MIT Press, http://web.stanford.edu/ johntayl/Onlinepaperscombinedbyyear/1985/International_Capit al_Mobility_and_the_Coordination_of_Monetary_Rules.pdf

Caruana, Jamie (2012a), “Policymaking in an Interconnected World,” presented at Federal Reserve Bank of Kansas City Policy Symposium on The Changing Policy Landscape, Jackson Hole, Wyoming, August 31

Caruana, Jamie (2012b), “International Monetary Policy Interactions: Challenges and Prospects,” Bank for International Settlements, Speech in Punta del Este, Uruguay, November 16 Chen, Qianying, Andrew Filardo, Dong He and Feng Zhu (2012),’International Spillovers of Central Bank Balance Sheet Policies,” BIS Papers, Number 66

Christiano, Lawrence, Martin Eichenbaum, and Charles Evans (2005), "Nominal Rigidities and the Dynamic Effects of a Shock to Monetary Policy," Journal of Political Economy 113, 1: $1-45$

Clarida, Richard (2014) “Monetary Policy in Open Economies: Practical Perspectives for Pragmatic Central Bankers,” forthcoming in Journal of Economics Dynamics and Control

Clarida, Richard, Jordi Gali, and Mark Gertler (1998), “Monetary Policy Rules in Practice: Some International Evidence,” European Economic Review, 42 (6), 1033-1067 
Clarida, Richard, Jordi Gali and Mark Gertler (2002), “A Simple Framework for International Monetary Policy Analysis," Journal of Monetary Economics 49: 879-904

Eichengreen, Barry (2013), “Currency War or International Policy Coordination?” University of California, Berkeley, January http://eml.berkeley.edu/ eichengr/curr_war_JPM_2013.pdf

Fisher, Richard W. (2014), “Monetary Policy and the Maginot Line,” Remarks at the University of Southern California, July 16

Friedman, Milton (1962), Capitalism and Freedom, University of Chicago Press, Chicago Gagnon, Joseph, Matthew Raskin, Julie Remanche, and Brian Sack (2011), “The Financial Market Effects of the Federal Reserve’s Large-Scale Asset Purchases,” International Journal of Central Banking, vol. 7(1), 3 - 44

Gray, Colin (2013), “Responding to a Monetary Superpower: Investigating the Behavioral Spillovers of U.S. Monetary Policy,” Atlantic Economic Journal, June, Volume 41, Issue 2, pp 173-184.

Hofmann, Boris and Bilyana Bogdanova (2012), “Taylor Rules and Monetary Policy: A Global Great Deviation?” BIS Quarterly Review, September 2012

Kahn, George A. (2010), “Taylor Rule Deviations and Financial Imbalances.” Federal Reserve Bank of Kansas City Economic Review, Second Quarter, 63-99.

King, Mervyn (2003) "Speech at the East Midlands Development Agency/Bank of England Dinner,” Leicester, October 14

King, Mervyn (2012), “Twenty years of Inflation Targeting,” Stamp Memorial Lecture, London School of Economics, London, October 9 
Nikolsko-Rzhevskyy, Alex, David H. Papell, Ruxandra Prodan (2014), “Deviations from RulesBased Policy and Their Effects,” forthcoming Journal of Economic Dynamics and Control

Obstfeld, Maurice (2014), “On the Use of Open Economy New Keynesian Models to Evaluate Policy Rules,” forthcoming in Journal of Economic Dynamics and Control,

Obstfeld, Maurice and Kenneth Rogoff (2002), “Global Implications of Self-Oriented National Monetary Rules,” Quarterly Journal of Economics, 117, 503-536.

OECD (2010) Economic Survey: Norway, p. 32

Rey, Hélène (2013) “Dilemma not Trilemma: The Global Financial Cycle and Monetary Policy Independence,” in Global Dimensions of Unconventional Monetary Policy, Federal Reserve Bank of Kansas City, August

Røisland, Øistein (2010), “Monetary Policy in Norway,” Slide presentation, Norges Bank http://www.uio.no/studier/emner/sv/oekonomi/ECON4325/v10/undervisningsmateriale/ MonetaryPolicyNorway.pdf

Smets, Frank and Raf Wouters. (2007). "Shocks and Frictions in U.S. Business Cycles: A Bayesian DSGE Approach." American Economic Review 97, 3: 506-606.

Stroebel, Johannes and John B. Taylor (2012), “Estimated Impact of the Fed’s Mortgage-Backed Securities Purchase Program,” International Journal of Central Banking, 8 (2), June 2012, pp. 1-42

Taylor, John B. (1979), “Estimation and Control of a Macroeconomic Model with Rational Expectations,” Econometrica, 47 (5), September, pp. 1267-1286

Taylor, John B. (1980), “Aggregate Dynamics and Staggered Contracts,” Journal of Political Economy, 88 (1), February 1980, pp. 1-23. 
Taylor, John B. (1985), "International Coordination in the Design of Macroeconomic Policy Rules,” European Economic Review, 28, 1985, pp. 53-81

Taylor, John B. (1993), Macroeconomic Policy in a World Economy: From Econometric Design to Practical Operation, W.W. Norton, New York

Taylor, John B. (2007), “Housing and Monetary Policy,” in Housing, Housing Finance, and Monetary Policy, Federal Reserve Bank of Kansas City, Sept., pp. 463-476.

Taylor, John B. (2009) “Globalization and Monetary Policy: Missions Impossible,” in Mark Gertler and Jordi Gali (Eds.) The International Dimensions of Monetary Policy, The University of Chicago Press, 2009, pp. 609-624

Taylor, John B. (2013a), “Lectures on Monetary Theory and Policy,” Stanford University http://web.stanford.edu/ johntayl/Spring2013PhDclass/IndexSpring2013.html

Taylor, John B. (2013b), “International Monetary Coordination and the Great Deviation,” Journal of Policy Modeling, Volume 35, (3), May/June 2013, pp. 463-472

Taylor, John B Taylor (2013c), “International Monetary Policy Coordination: Past, Present and Future,” BIS Working Papers, No 437, Monetary and Economic Department, December

Taylor, John B. and Volker Wieland (2012) “Surprising Comparative Properties of Monetary Models: Results from a New Model Data Base,” Review of Economics and Statistics, 94 (3), August, pp. 800-816

Vegh, Carlos and Guillermo Vuletin (2012), “Overcoming the fear of free falling: Monetary policy graduation in emerging markets,” NBER Working Paper No. 18175, June.

Volcker, Paul (2014), “Remarks,” Bretton Woods Committee Annual Meeting, June 17 http://www.brettonwoods.org/sites/default/files/publications/Paul\%20Volcker\%20final\% 20Remarks\%20June\%2017.pdf 
Wieland, Volker, Tobias Cwik, Gernot Mueller, Sebastian Schmidt, Maik Wolters (2012),"A New Comparative Approach to Macroeconomic Modeling and Policy Analysis," Journal of Economic Behavior and Organization, Vol. 83 No. 3 (August), pp. 523-541.

Yellen, Janet (2013), “Revolution and Evolution in Central Bank Communications,” Haas School of Business, University of California, Berkeley, November 13 